X Stories, Myths, Chants, and Songs of the Kuna Indians

\title{
List of Photographs
}

\section{by Joel Sherzer (photo section follows page 125)}

1. Pedro Arias speaking in the Mulatuppu gathering house

2. Hortenciano Martínez writing in a notebook

3. Chief Nipakkinya watching a sporting event

4. Anselmo Urrutia working with a tape recorder

5. Pranki Pilos wearing his medicinal specialist's clothing and carrying his staff

6. Olowiktinappi gathering medicine in the jungle

7. Olowiktinappi making a basket

8. Olowiktinappi performing The Way of the Rattlesnake

9. Chief Mastaletat

10. Woman grinding sugarcane to make chicha

11. Men grinding sugarcane to make chicha

12. Chicha in pots

13. Men stirring chicha

14. Chicha fermenting

15. Pedro Arias sitting in front of fermented chicha

16. Kantule Ernesto Linares and his assistant, Andrew García, performing during puberty rites

17. Meristante Diaz and Rogelio Robles playing long flutes during puberty festivities

18. Women preparing ritual meal for puberty festivities

19. Women eating ritual meal during puberty festivities

20. Men eating ritual meal during puberty festivities

21. Jerónimo Green and Alfredo Martínez preparing hammock for puberty festivities

22. The island/village of Mulatuppu

23. Tiowilikinya

24. Juliana Quijano dressed for puberty festivities

25. Women at puberty festivities

26. Woman at puberty festivities

27. Women at puberty festivities

28. Benilda Quijano with baby 


\section{Stories, Myths, Chants, and Songs of the Kuna Indians}




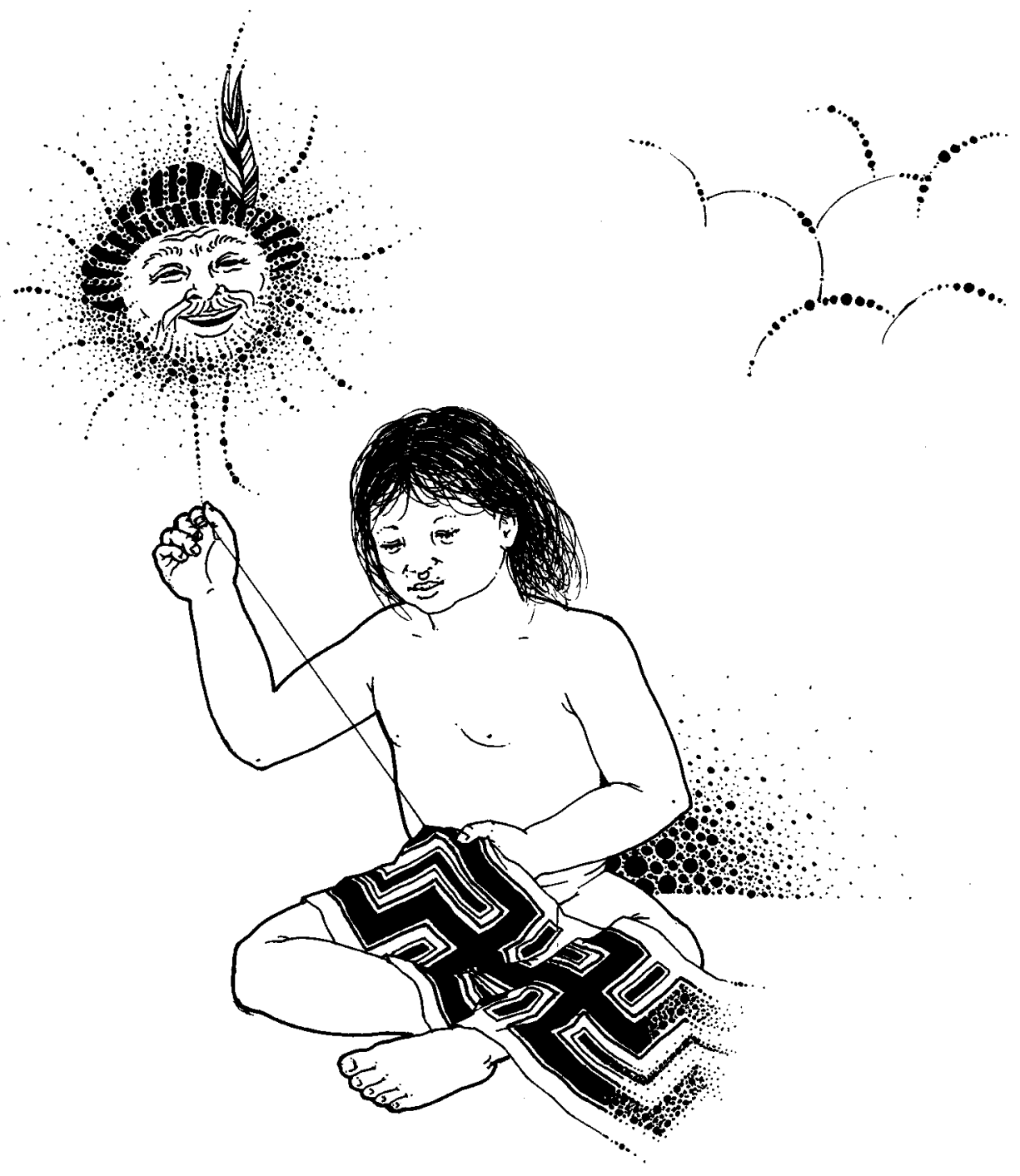

Figure 1. Young girl making a mola 